\title{
A comparative analysis of elasticity modulus of recycled aggregate concrete with silica fume
}

\author{
Silis dumanı katkılı geri kazanılmıș agregalı betonların elastisite \\ modüllerinin karşılaştırmalı analizi
}

\author{
Özgür ÇAKIR ${ }^{1}$ iD, Hasan DILLAS ${ }^{2}$ iD \\ ${ }^{1}$ Civil Engineering Department, Faculty of Civil Engineering, Yildiz Technical University, Istanbul, Istanbul, Turkey. \\ cozgur@yildiz.edu.tr \\ ${ }^{2}$ Civil Engineering Department, Faculty of Engineering, Yuzuncu Yil University, Van, Turkey. \\ hasandilbas@yyu.edu.tr
}

Received/Geliş Tarihi: 09.11.2017, Accepted/Kabul Tarihi: 12.03.2018

doi: $10.5505 /$ pajes.2018.92489

* Corresponding author/Yazıșllan Yazar Research Article/Araștırma Makalesi

\begin{abstract}
Recycling of waste materials has significant influence on the concept of sustainability in construction industry due to the conservation of natural resources and minimizing the environmental impacts which leads to habitable future. Construction activities, in general, result in huge amount of construction and demolition waste (C\&DW) and C\&DW has a great potential for possible disposal as recycled aggregate $(R A)$ in civil engineering applications, especially in recycled aggregate concrete (RAC), after recycling processes. In this concept, concrete mixtures including $R A$ and silica fume (SF) at various ratios (0-30-40-70-100\%) and (0-5-10\%), respectively, are produced in order to determine the elasticity modulus of RAC. This work aims to examine elasticity modulus of RAC determined according to the formulas of standards and studies. Analytical and statistical assessments are performed and experimental and theoretical results are compared. When $R A$ content increases, the elasticity modulus decreases. SF utilization in RAC improves the mechanical parameters (elasticity modulus and compressive strength). The American standard (ACI 318-05) predicts the elasticity modulus approximately to the experimental results although it has the highest relative standard deviations in comparison to the regarded standards. Moreover, proposed equations for RAC by researchers estimate the elasticity modulus values greater than those of standards and the experimental results. An elasticity modulus equation is also proposed for RAC with and without SF.
\end{abstract}

Keywords: Recycled aggregate concrete, Silica fume, Elasticity modulus, Standards

\section{Introduction}

The change in the human demands requires much more resources due to overconsumption. Hence, it causes intensive utilization of natural sources in many countries. As a result, aggregate shortage for concrete production commences to occur [1]. Moreover; rapid growing of urbanization around the world produces great-amount of construction and demolition waste (C\&DW). It is clear that disequilibrium between the excessive usage of natural sources and increasing amount of C\&DW is in contradiction with the sustainability concept. The gap between excessive consumption of natural resources and C\&DW generation is growing day after day. Nowadays, in order to amend the disequilibrium, the researches are conducted
Öz

Atık malzemelerin geri dönüşümü, doğal kaynakların korunmasından ve yaşanabilir bir gelecek için öncülük edecek çevresel etkilerinin azaltılmasından dolayı, yapı sektöründe sürdürülebilirlik kavramı üzerinde önemli bir etkiye sahiptir. Yapım ișlemleri, genellikle, yüksek miktarda yapı ve yıkıntı atığı (YYA) oluşumuyla sonuçlanmakta ve geri dönüşüm işlemi ardından YYA bertaraf edilmesi için inşaat mühendisliği uygulamalarında, özellikle geri kazanılmış agregalı betonda (GKA-B), geri kazanılmış agrega (GKA) olarak kullanımı büyük potansiyele sahiptir. $\mathrm{Bu}$ bağlamda, ceșitli oranlarda GKA (0-30-40-70-100\%) ve çeşitli oranlarda silis dumanı (SD) (0-5-10\%) içeren beton karıșımları GKA-B' nun elastisite modülünü belirlemek üzere üretilmiştir. Bu çalışma, çeşitli standartlar tarafindan ve çeşitli araştırmacılar tarafından önerilen teorik elastisite modülü formüllerince hesaplanan GKA-B elastisite modülü değerlerinin deneysel olarak elde edilen GKA-B elastisite modülü değerlerine yakınlıklarının olup olmadığını göstermeyi amaçlamaktadır. Analitik ve istatistik değerlendirmeler yapılmıştır. Sonuç olarak, GKA oranının betondaki artışı ile elastisite modülü azalmaktadır. GKA-B'da SD kullanımı elastisite modülünü ve basınç dayanımını artırmaktadır. Irdelenen standartlar göz önüne alındığında, Amerikan standardı (ACI 318-05) elastisite modülünü deneysel sonuçlara göre, en yüksek standart sapma göstermesine rağmen, yakın tahmini vermektedir. Diğer taraftan araștırmacılar tarafından GKA-B elastisite modülü tahmini için önerilen denklemler, irdelenen standartların ve deney sonuçlarının üzerinde sonuç vermektedirler. SD içeren ve içermeyen betonlar için bir elastisite modülü denklemi de bu çalıșmada önerilmektedir.

Anahtar kelimeler: Geri kazanılmış agregalı beton (GKA-B), Silis dumanı (SD), Elastisite modülü, Standartlar

with a aim of C\&DW use in concrete as recycled aggregate (RA), and many of studies intend to examine the RA

effect on concrete behaviour (fresh state and hardened state) [2]-[4]. Using RA reduces the need for virgin aggregates but modifies the engineering parameters of concrete.

Design parameters of materials are crucial for engineering structures. In many times, it may not be possible to conduct all material tests due to limited time, high costs of tests etc. Hence the strong relations between material properties are used to obtain approximate value of engineering parameters. The relationship among engineering parameters of concrete is wellknown (i.e., elasticity modulus-compressive strength relation). In this concepts, many codes present formulas to estimate approximate values of elasticity modulus [5]-[10]. For instance, 
CSA A23.3-04, EN 1992-1-1, ACI 318M-05 and TS 500 propose equations considering an independent variable (it is compressive strength of concrete) [5]-[10]. Also, many researchers examined parameters of concrete such as densitywater absorption relation, elasticity modulus-compressive strength relation) [11]-[14,][24]. Demir and Korkmaz used fuzzy logic considering compressive strength to estimate elasticity modulus, then determined upper and lower limits of elasticity modulus [15]. Vilanova et al. examined elasticity modulus equations proposed by standards and used compressive strengths given in literature [12]. They found that ACI 318-08 overestimated the measured elasticity modulus. Corinaldesi produced 15 mixes [16]. A formula was proposed in Ref. [16] to estimate moduli of elasticity, then the obtained results are compared with the results of many formulas proposed in the recent literature. According to many codes and the studies, if a concrete parameter is easily determined in an experiment, a required parameter can be estimated using theoretical formulas/methods (here, there should be a relation between the parameter and the estimated parameter). Hence, the above described approach gives an opportunity to obtain approximate value of concrete parameters.

In case of natural aggregate concrete (NAC), various formulas for determining elasticity modulus given in different standards are widely used by designers and researchers [5],[6],[9],[17]. On the other hand, many formulas developed by using the experimental results are given in the related literature (i.e., [13],[15],[18]). Zhou et al. used composite models to estimate elasticity modulus [13] and reported that Ramesh model was able to estimate theoretically the modulus of elasticity. Yıldırım and Sengul examined elasticity modulus of substandard and normal concretes [18]. Also Yıldırım and Sengul offered formulas for elasticity modulus of concretes comparing them with the results obtained according to standards [18]. Demir and Korkmaz used fuzzy logical algorithm to determine lower and upper limits of elasticity moduli and found that fuzzy logic method performed more realistic results and is useful to estimate the limits of elasticity moduli [15].

It is well-known that elasticity modulus of concretes vary due to the parameters (i.e., aggregate type, mineral additives, super plasticizer (SP), water/binder (w/b)). In case of RAC, if other parameters of RAC are assumed constant, use of RA with heterogeneous structure strongly influences the behavior of concrete (i.e. compressive strength). RA is porous and heterogeneous, as well as a high impurities content [4]. Generally, RA incorporation in concrete affects the performance of RAC negatively. This can be concluded by the various characteristics of RA from those of NA. RA consists of NA and attached old cement paste. Hence when RA is used in concrete, phases are occurred in RAC, as a) recycled aggregate and attached old cement paste, b) recycled aggregate and new cement paste, c) natural aggregate (due to recycled aggregate) and new cement paste, d) new cement paste and attached old cement paste.

It is pointed out by various studies that, due to use of RA in concrete, density and water absorption are negatively influenced [3],[19],[20]. As a result of lower density of attached old cement paste in RA, the density of RAC will be lower in comparison to NAC [3]. Just the opposite, the water absorption increases when RA ratio increases in RAC [3]. Besides, according to higher water absorption ratio of RA, presaturation of RA and SP effects are investigated [21],[22]. The authors stated that pre-saturation process of RA is not suitable for mechanical performance in comparison to the mixing water compensation method [23]. However, using SP is caused an increase of compressive strength at lower w/b. Also, it is reported that SP accelerates strength improvement in a short time [22]. Furthermore, it is pointed out that crushing process affects the discontinuity in the structure of RA [3],[24]. However, the performance variation of RAC due to different crushing processes is found limited (6\%) [22].

Concrete's elasticity modulus is strongly dependent on the phases of stiffness (these are interfacial transition zones, cement paste and aggregates) [25]. RA with low properties (i.e. higher porosity, low elasticity modulus) is the weakest point in concrete [3]. The contaminants, low strength and low density etc. of RA are the poor properties. According to this, RA is found effective on the mechanical performance of RAC $[3],[26]-[29]$. Hence, it can be stated that higher deformability of RAC due to RA in comparison to NAC is considerably reasoned by lower elasticity modulus of RA [3],[29]. It is reported that RA strength (at medium and high level) has a little influence on RAC parameters although low quality of RA has higher water absorption and porosity, and hence this leads lower stiffness of concrete [26]. However, some contaminants (i.e. brick and tile) did not have considerable effect on elasticity modulus of RAC [3]. Also, the usage of additional materials (i.e., chemical admixtures, mineral additions) in conventional concretes is found useful for RAC to improve the low properties of RAC (i.e. higher porosity, low elasticity modulus) [30]-[32].

Based on the explanations given above, there is a strong relation between the mechanical properties (i.e., compressive strength-elasticity modulus). Hence, elasticity modulus formulas for concretes included NA and RA are developed considering compressive strength values [33]-[35]

It can be seen from the literature that many researchers propose elasticity modulus equations and/or use equations given in standards (i.e., Refs. [36]-[38]). However, there is only few studies examined elasticity modulus of RAC considering equations proposed in both literature and standards. Also, only few proposed equations by researchers are examined clearly in the literature considering various research results and the predictability of the proposed equations. It is expected that previously existing relations given by many researchers don't work due to the various effective parameters (i.e., impurities in $\mathrm{RA}$, super plasticizer, w/b) on RAC. A distinctive elasticity modulus formula derivation can be more appropriate for each different RAC. This paper aims to examine elasticity modulus of RAC determined according to the formulas of standards and studies. Analytical and statistical assessments are performed and experimental and theoretical results are compared to each other. Also, an elasticity modulus equation for RAC with and without SF based on this experimental results is proposed to contribute the literature. The specimens contained 0-30-40-70$100 \%$ RA and $0-5-10 \%$ silica fume (SF) are produced in the laboratory. The tests are applied at the age of 28 days. Then, also, elasticity modulus (chord elasticity modulus and tangent elasticity modulus) are calculated by using stress-strain data recorded while compressive strength test is being conducted. Then, the experimental elasticity modulus results are analyzed in comparison to standards [5],[6],[9],[17] and the elasticity modulus equations proposed by researchers [16],[33],[39],[40] and by the authors in this study. 


\section{Experimental stage}

Fifteen groups of concrete mixtures are produced in laboratory. The slump classes of mixes are selected as S4 for fresh state of concretes. The notations of the specimens are defined (Table 1).

Table 1: The notations.

\begin{tabular}{|c|c|c|}
\hline & Notation & Definition \\
\hline \multirow{5}{*}{ 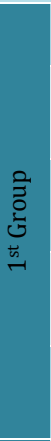 } & NAC & $\begin{array}{l}\text { Concrete with natural aggregates such as natural } \\
\text { sand, natural fine, and natural coarse }\end{array}$ \\
\hline & RA1C & $\begin{array}{l}\text { Recycled aggregate concrete with recycled } \\
\text { aggregate and natural aggregate such as } \\
\text { recycled fine, natural coarse and natural sand }\end{array}$ \\
\hline & RA2C & $\begin{array}{l}\text { Recycled aggregate concrete with recycled } \\
\text { aggregate such as natural fine, recycled coarse } \\
\text { and natural sand }\end{array}$ \\
\hline & RA12C & $\begin{array}{l}\text { Recycled aggregate concrete with recycled } \\
\text { aggregate and natural aggregate such as } \\
\text { recycled fine, recycled coarse and natural sand }\end{array}$ \\
\hline & RA123C & $\begin{array}{l}\text { Recycled aggregate concrete with recycled } \\
\text { aggregate such as recycled fine, recycled coarse } \\
\text { and recycled sand }\end{array}$ \\
\hline \multirow{5}{*}{ 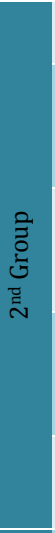 } & NACSF5 & $\begin{array}{l}\text { Concrete with natural aggregate such as natural } \\
\text { fine, natural coarse and natural sand, and } 5 \% \mathrm{SF}\end{array}$ \\
\hline & RA1CSF5 & $\begin{array}{l}\text { Recycled aggregate concrete with recycled } \\
\text { aggregate and natural aggregate such as } \\
\text { recycled fine, natural coarse and natural sand, } \\
\text { and } 5 \% \mathrm{SF}\end{array}$ \\
\hline & RA2CSF5 & $\begin{array}{l}\text { Recycled aggregate concrete with recycled } \\
\text { aggregate and natural aggregate such as natural } \\
\text { fine, recycled coarse and natural sand, and } 5 \% \\
\text { SF }\end{array}$ \\
\hline & RA12CSF5 & $\begin{array}{l}\text { Recycled aggregate concrete with recycled } \\
\text { aggregate and natural aggregate such as } \\
\text { recycled fine, recycled coarse and natural sand, } \\
\text { and } 5 \% \mathrm{SF}\end{array}$ \\
\hline & RA123CSF5 & $\begin{array}{l}\text { Recycled aggregate concrete with recycled } \\
\text { aggregate such as recycled fine, recycled coarse } \\
\text { and recycled sand, and } 5 \% \mathrm{SF}\end{array}$ \\
\hline \multirow{5}{*}{ 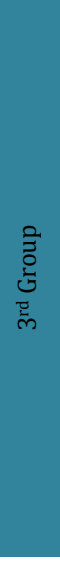 } & NACSF10 & $\begin{array}{l}\text { Concrete with natural aggregate such as natural } \\
\text { fine, natural coarse and natural sand, and } 10 \% \\
\text { SF }\end{array}$ \\
\hline & RA1CSF10 & $\begin{array}{l}\text { Recycled aggregate concrete with recycled } \\
\text { aggregate and natural aggregate such as } \\
\text { recycled fine, natural coarse and natural sand, } \\
\text { and } 10 \% \mathrm{SF}\end{array}$ \\
\hline & RA2CSF10 & $\begin{array}{l}\text { Recycled aggregate concrete with recycled } \\
\text { aggregate and natural aggregate such as natural } \\
\text { fine, recycled coarse and natural sand, and } 10 \% \\
\text { SF }\end{array}$ \\
\hline & RA12CSF10 & $\begin{array}{l}\text { Recycled aggregate concrete with recycled } \\
\text { aggregate and natural aggregate such as } \\
\text { recycled fine, recycled coarse and natural sand, } \\
\text { and } 10 \% \mathrm{SF}\end{array}$ \\
\hline & RA123CSF 10 & $\begin{array}{l}\text { Recycled aggregate concrete with recycled } \\
\text { aggregate such as recycled fine, recycled coarse } \\
\text { and recycled sand, and } 10 \% \mathrm{SF}\end{array}$ \\
\hline
\end{tabular}

Specimens with cylindrical shape and $150 \$ 300 \mathrm{~mm}$ dimensions cured for 28-days. While the design of mixtures, TS 802 is considered [41]. The concrete strength class is chosen as C30/37. The diameter of the maximum aggregate size $\left(D_{\max }\right)$ is chosen as $31.5 \mathrm{~mm}$. The dosage of the concrete mixes are 350 $\mathrm{kg} / \mathrm{m}^{3}$ CEM I 42.5R Portland cement (PC). Also SF is used and is compatible with ASTM C 1240-12 (Table 2). The curing conditions are suitable with TS EN 12390-2 (2010) [42].

It is known that mineral addition (i.e., SF and fly ash) in the RAC, improves the properties (i.e., mechanical and physical properties) of RAC [32]. Hence, SF is used in the mixtures and is replaced by weight of cement at various ratios $(0-5-10 \%)$. The utilized aggregate types are basalt aggregate and siliceous sand as NA, and C\&DW as RA.
Table 2: SF and cement properties.

\begin{tabular}{|c|c|c|c|}
\hline Contents & SF & Contents & Cement \\
\hline $\mathrm{SiO}_{2}$ & $>85 \%$ & $\mathrm{Fe}_{2} \mathrm{O}_{3}(\%)$ & 3.5 \\
\hline $\mathrm{CaO}$ & $<1 \%$ & $\mathrm{CaO}(\%)$ & 64.9 \\
\hline $\mathrm{SO}_{3}$ & $<2 \%$ & $\mathrm{SiO}_{2}(\%)$ & 22.0 \\
\hline Color & Amber & $\operatorname{MgO}(\%)$ & 0.9 \\
\hline $\begin{array}{c}\text { Structure of } \\
\text { material }\end{array}$ & $\begin{array}{l}\text { Condensed } \\
\text { microsilica }\end{array}$ & $\mathrm{Al}_{2} \mathrm{O}_{3}(\%)$ & 5.9 \\
\hline $\begin{array}{c}\text { Chlorine ratio } \\
(\%)\end{array}$ & $<1$ & $\mathrm{SO}_{3}(\%)$ & 2.7 \\
\hline Density (kg/liter) & $0.55-0.70$ & $\begin{array}{c}\text { Specific gravity } \\
\left(\mathrm{gr} / \mathrm{cm}^{3}\right)\end{array}$ & 3.16 \\
\hline Activity index (\%) & $>95$ & $\begin{array}{c}\text { Loss on ignition } \\
(\%)\end{array}$ & 1.2 \\
\hline $\begin{array}{l}\text { Particle ratio } \\
(<0,045 \mathrm{~mm})\end{array}$ & $<40 \%$ & $\begin{array}{c}\text { Specific surface } \\
\text { area }\left(\mathrm{cm}^{2} / \mathrm{gr}\right)\end{array}$ & 3540 \\
\hline $\begin{array}{l}\text { Specific surface } \\
\text { area }\left(\mathrm{m}^{2} / \mathrm{kg}\right)\end{array}$ & 15000 & & \\
\hline
\end{tabular}

In this study, NA is replaced with RA. The replacement of NA considering natural coarse aggregate $(4-8 \mathrm{~mm})$ (NA1), natural coarse aggregate (4-32 $\mathrm{mm}$ ) (NA2) and natural sand (0-4mm) (NA3) is done with RA considering recycled coarse aggregate (4-8mm) (RA1), recycled coarse aggregate (4-32mm) (RA2) and recycled sand (0-4 $\mathrm{mm}$ ) (RA3), respectively. The utilization ratios of "NA1 and RA1", "NA2 and RA2", and "NA3 and RA3" are $40 \%, 30 \%$ and $30 \%$, respectively. RAs are obtained crushing the C\&DW. The concrete mixtures are contained 0-5$10 \%$ SF. The components of concrete mixes are given in Table 3 . Figure 1 presents aggregates gradation curves considered in this paper. Aggregates such as recycled aggregate (i.e., RA1, RA2 and RA3) and natural aggregate (i.e., NA1, NA2 and NA3) are utilized. Also a constant water to binder ratio is considered and selected for all concretes as 0.5 .

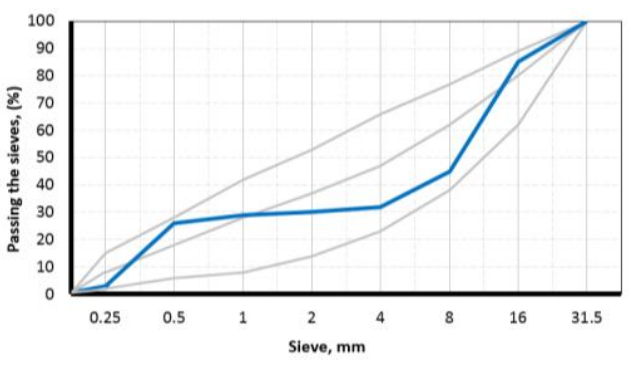

Figure 1: Gradation of aggregate.

RA sources of the C\&DW in Istanbul. Crushing is applied to C\&DW in the laboratory using a jaw crusher. In the first step, the collection of C\&DW without any classification is done demolition area. Then C\&DW is crushed. Small pieces with diameters $<30 \mathrm{~mm}$ are obtained in the laboratory by using hammer manually. A jaw crusher, in the second step, is used to adjust C\&DW diameters $<30 \mathrm{~mm}$. Then crushed material is classified using sieves. RA1 (4-8mm), RA2 (8-32 mm) and RA3 (0-4mm) have same particle sizes with NA1 (4-8 mm), NA2 (8-32mm) and NA3 $(0-4 \mathrm{~mm})$ in this research, respectively. Impurities of RA are shown in Figure 2.

The properties of aggregates are obtained according to TS EN 1097-6/AC (2006) [43] and TS EN 1097-2 (2010) [44]. Also, chemical properties of aggregates are obtained (TS EN 1744-1) [45]. The defined properties of aggregates are in Table 4. 

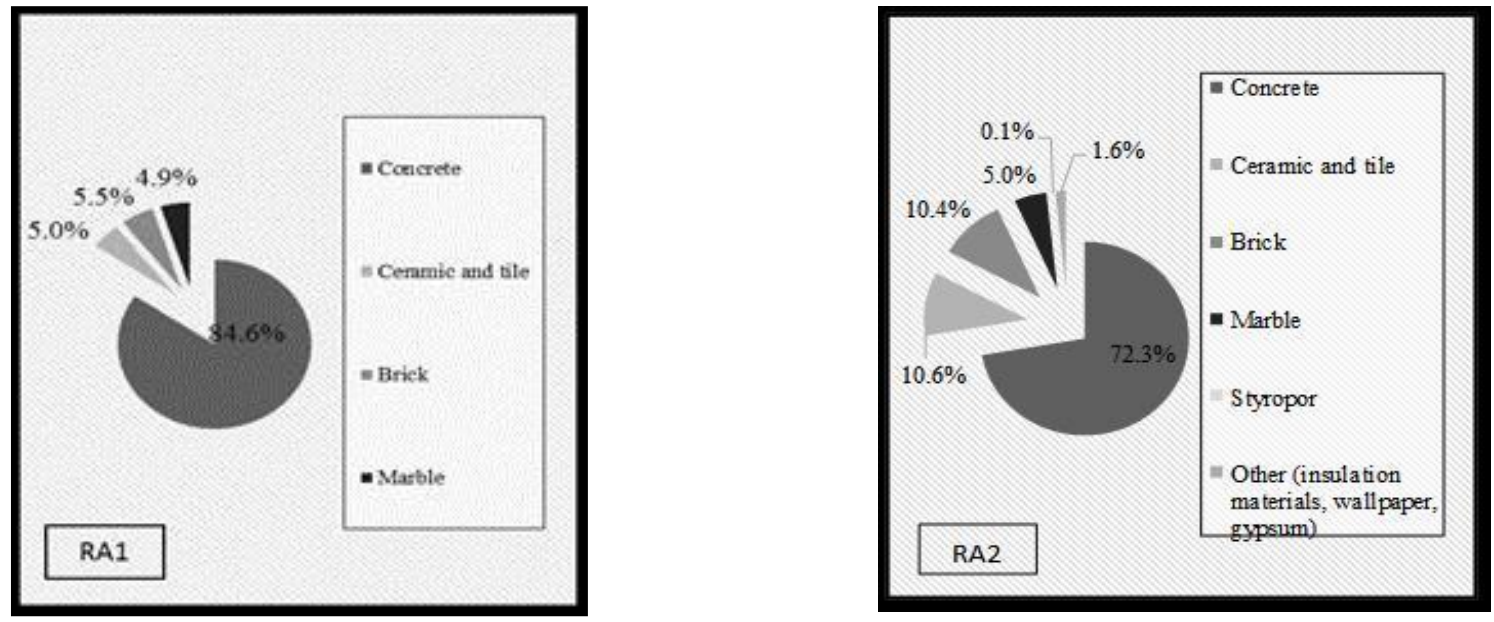

Figure 2: Contents of RA1 and RA2.

Table 3: Mix proportions of concrete.

\begin{tabular}{|c|c|c|c|c|c|c|c|c|c|c|c|}
\hline \multirow{3}{*}{ Mix } & \multicolumn{11}{|c|}{ Contents $\left(\mathrm{kg} / \mathrm{m}^{3}\right)$} \\
\hline & \multicolumn{2}{|c|}{ Water } & \multicolumn{2}{|c|}{ Binder } & \multirow{2}{*}{ 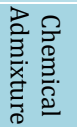 } & \multicolumn{3}{|c|}{ Natural Aggregate } & \multicolumn{3}{|c|}{ Recycled Aggregate } \\
\hline & Initial & Effective & Cement & SF & & NA1 & NA2 & NA3 & RA1 & RA2 & RA3 \\
\hline $\mathrm{NAC}$ & 175 & 177.2 & 350.0 & 0 & 0.096 & 777 & 576 & 538 & 0 & 0 & 0 \\
\hline RA1C & 175 & 187.2 & 350.0 & 0 & 0.289 & 0 & 576 & 538 & 648 & 0 & 0 \\
\hline RA2C & 175 & 186.0 & 350.0 & 0 & 0.289 & 777 & 0 & 538 & 0 & 463 & 0 \\
\hline RA12C & 175 & 196.0 & 350.0 & 0 & 0.289 & 0 & 0 & 538 & 648 & 463 & 0 \\
\hline NACSF5 & 175 & 177.2 & 332.5 & 17.5 & 0.289 & 777 & 576 & 538 & 0 & 0 & 0 \\
\hline RA1CSF5 & 175 & 187.2 & 332.5 & 17.5 & 0.385 & 0 & 576 & 538 & 648 & 0 & 0 \\
\hline RA2CSF5 & 175 & 186.0 & 332.5 & 17.5 & 0.385 & 777 & 0 & 538 & 0 & 463 & 0 \\
\hline RA12CSF5 & 175 & 196.0 & 332.5 & 17.5 & 0.385 & 0 & 0 & 538 & 648 & 463 & 0 \\
\hline RA123CSF5 & 175 & 201.8 & 332.5 & 17.5 & 0.420 & 0 & 0 & 0 & 648 & 463 & 486 \\
\hline NACSF10 & 175 & 177.2 & 315.0 & 35.0 & 0.501 & 777 & 576 & 538 & 0 & 0 & 0 \\
\hline RA1CSF10 & 175 & 187.2 & 315.0 & 35.0 & 0.462 & 0 & 576 & 538 & 648 & 0 & 0 \\
\hline RA2CSF10 & 175 & 186.0 & 315.0 & 35.0 & 0.385 & 777 & 0 & 538 & 0 & 463 & 0 \\
\hline RA123CSF10 & 175 & 201.8 & 315.0 & 35.0 & 0.420 & 0 & 0 & 0 & 648 & 463 & 486 \\
\hline
\end{tabular}

Table 4: The properties of aggregates.

\begin{tabular}{|c|c|c|c|c|c|c|c|c|c|}
\hline స్ర్ర & 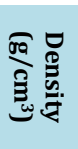 & 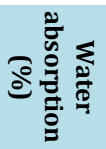 & 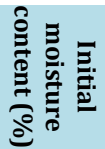 & 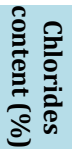 & 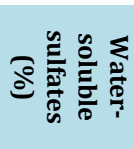 & 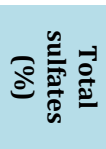 & 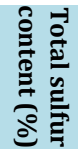 & 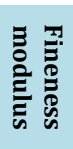 & 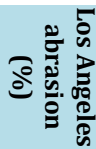 \\
\hline NA1 & 2.75 & 0.8 & 0.67 & - & - & - & - & 5.57 & - \\
\hline NA2 & 2.72 & 0.6 & 0.53 & - & - & - & - & 6.41 & 24.32 \\
\hline NA3 & 2.55 & 1.2 & 1.05 & - & - & - & - & 2.12 & - \\
\hline RA1 & 2.33 & 3.8 & 2.10 & 0.57 & 0.65 & 0.76 & 0.81 & 5.50 & - \\
\hline RA2 & 2.23 & 4.3 & 2.32 & 0.53 & 0.71 & 0.80 & 0.86 & 6.44 & 41.40 \\
\hline RA3 & 2.20 & 3.5 & 2.04 & 0.52 & 0.63 & 0.78 & 0.82 & 2.20 & - \\
\hline
\end{tabular}

Super plasticizer (SP) based on polycarboxylic ether is used in concrete production to enhance low workability of the mixtures. The workability of all mixtures is constant and slump class of mixes is set to S4. It is expected that the workability of RAC mixtures are low due to the shape characteristics of crushed RA (i.e., the texture of granular surface and greater angularity) in comparison to the shape characteristics of NA (i.e., the smooth and rounded shape). Owing to its high water absorption rate, the RA1 and RA2 are pre-soaked in water for 24 hours before casting, and also RA3 is passed through the same process. Hence SP amount is approximately same for the mixes while increasing RA content in the mixtures (Table 3). Also S4 slump class is obtained adding SP in small quantities step by step and determining slump value at every step. Hence bleeding or segregation for all concrete mixtures is not observed.

Fifteen groups of fresh concretes are produced and fresh concretes are vibrated by using shaking table to compact properly. The hardened samples are kept in lime-saturated water at a temperature of $20 \pm 2{ }^{\circ} \mathrm{C}$ until 28 days. Compressive strength test and elasticity moduli test are carried out on three samples (150\$300 mm cylindrical) of each group. In total, 45 
cylindrical specimens $(150 \$ 300 \mathrm{~mm})$ are tested at the age of $28^{\text {th }}$ day. The compressive strengths of specimens are determined in accordance with TS EN 12390-3 (2010) [46]. The test results of compressive strength are presented in Table 5 . The elasticity modulus test is performed in accordance with ASTM C 469 [47]. The elasticity modulus test setup is shown in Figure 3.

\section{Stress-Strain data analysis}

The elasticity moduli experiments are conducted on $150 \phi 300$ $\mathrm{mm}$ cylindrical specimens and the data of load-displacement are assessed and recorded properly. the experiments. Stresses and strains are calculated using the recorded load-displacement data. Eq. (1) estimates the stress-strain data closer with the experimental data (coefficient of determination $\left.\left(R^{2}\right)>0.99\right)$ [48]. Hence Eq. (1) is utilized for all specimens as follows:

$$
\sigma=A \times \varepsilon-B \times \varepsilon^{2}
$$

Here, $\sigma$ and $\varepsilon$ is stress and strain, respectively.

According to EN-1992-1 [9], the curve of stress-strain in the rising branch can be portray by a second degree polynomial. In subsection 3.1.7 of EN-1992-1, Eq. (2) is given.

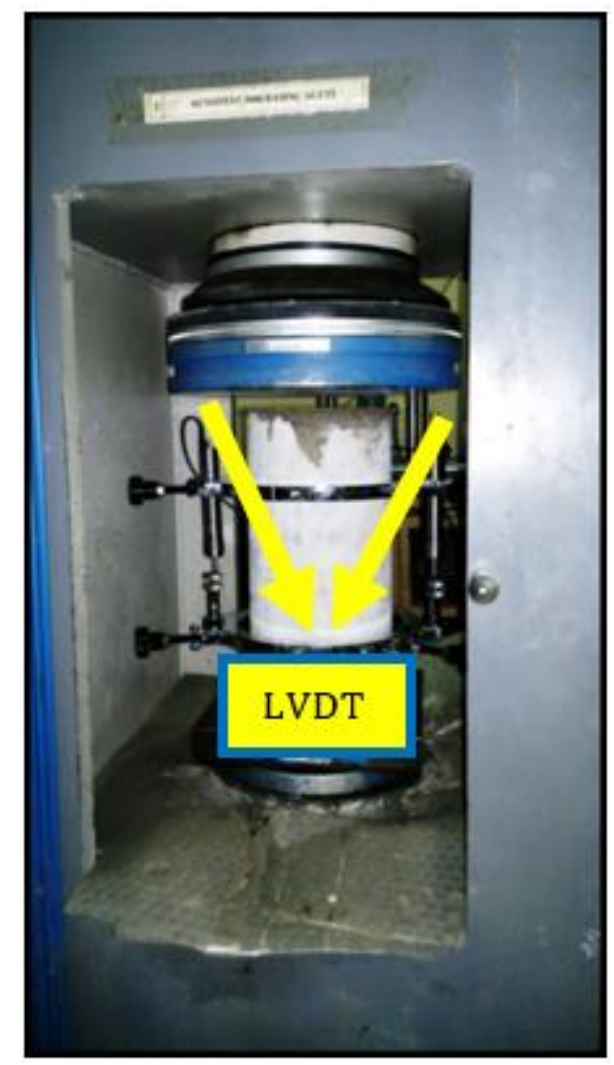

Figure 3: Elasticity modulus test setup.

Considering this situation, Eq. (1) is derived and the steps are given in below [4].

$$
f_{c}=f_{c d} \times\left[1-\left(1-\varepsilon_{c} / \varepsilon_{c 2}\right)^{2}\right]
$$

$$
f_{c}=\left(2 \times f_{c d} / \varepsilon_{c 2}\right) \times \varepsilon_{c}-\left(f_{c d} / \varepsilon_{c 2}^{2}\right) \times \varepsilon_{c}^{2}
$$

Because $\mathrm{f}_{\mathrm{cd}}$ and the corresponding $\varepsilon_{\mathrm{c} 2}$ are constants for a particular concrete, it is obvious from Eq. (2) that stress is a function of strain in the form of a $2^{\text {nd }}$ degree polynomial passing through the origin. With the symbols used herein, Eq. (1) can be written as:

$$
\sigma=A \times \varepsilon-B \times \varepsilon^{2}
$$

where, the coefficients A and B are defined as:

$$
\begin{gathered}
A=2 \times \sigma_{\max } /\left(\text { strain versus } \sigma_{\max }\right) \\
B=\sigma_{\text {max }} /\left(\text { strain versus } \sigma_{\text {max }}\right)^{2}
\end{gathered}
$$

As a result compatible with Eq. (3) and Eq. (3a) only a few $2^{\text {nd }}$ degree polynomials are fitted to stress-strain points and the equations of the most fitted curve functions are given in Table 6 for each concretes.

\subsection{Theoretical and experimental elasticity modulus calculations}

\subsubsection{Experimental elasticity modulus calculation}

Stress-strain curves of concretes are determined, elasticity modulus (tangent elasticity modulus (ETangent) and chord elasticity modulus ( $E_{\text {Chord}}$ )) of concretes are determined.

The moduli of elasticity are can be calculated as the chord modulus of elasticity and the tangent modulus of elasticity. Also, stress-strain curves are generated for each specimens using up to the stress equals to $70 \%$ of $\sigma_{\max }$ beyond the maximum stress $\sigma_{\max }$ (Figure 4).

The curves are also plotted for all concrete specimens, and are not given in the paper for conciseness. Also, the parameters of Eq. (1) (i.e., constants A and B) are determined and the results are given in Table 6 . Also the experimental elasticity modulus (EChord and $E_{\text {Tangent }}$ ) values are demonstrated in Table 6.

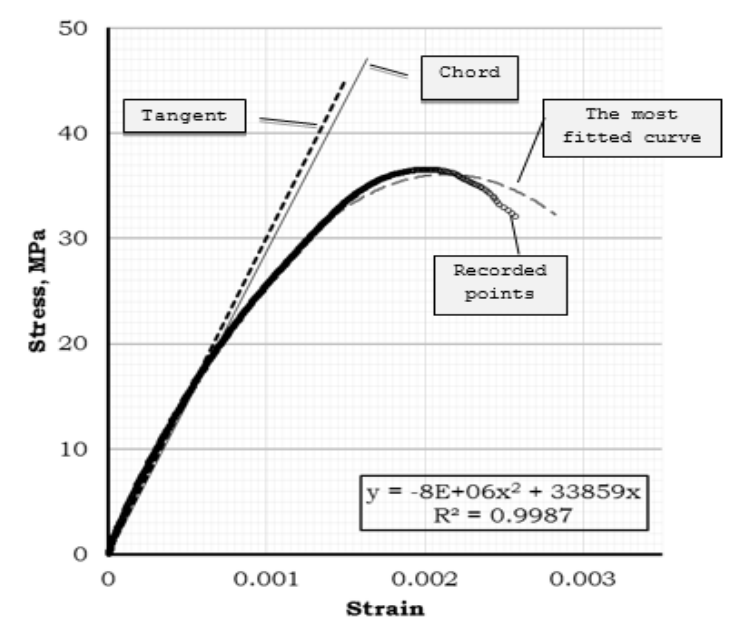

Figure 4: Stress-strain curve and the chord and the tangent lines for NAC specimen. 
Table 5: Compressive strength test results.

\begin{tabular}{|c|c|c|c|c|c|}
\hline Mixes & SF (\%) & RA (\%) & Slump (cm) & Slump Class & Compressive Strength (MPa) \\
\hline NAC & \multirow{5}{*}{0} & 0 & 17 & \multirow{15}{*}{ S4 } & 35.8 \\
\hline RA1C & & 40 & 19 & & 33.0 \\
\hline RA2C & & 30 & 18 & & 34.1 \\
\hline RA12C & & 70 & 18 & & 29.1 \\
\hline RA123C & & 100 & 18 & & 24.9 \\
\hline NACSF5 & \multirow{5}{*}{5} & 0 & 18 & & 39.9 \\
\hline RA1CSF5 & & 40 & 19 & & 34.8 \\
\hline RA2CSF5 & & 30 & 17 & & 35.2 \\
\hline RA12CSF5 & & 70 & 18 & & 33.2 \\
\hline RA123CSF5 & & 100 & 19 & & 30.6 \\
\hline NACSF10 & \multirow{5}{*}{10} & 0 & 19 & & 45.5 \\
\hline RA1CSF10 & & 40 & 16 & & 37.2 \\
\hline RA2CSF10 & & 30 & 20 & & 38.5 \\
\hline RA12CSF10 & & 70 & 16 & & 28.9 \\
\hline RA123CSF10 & & 100 & 17 & & 31.3 \\
\hline
\end{tabular}

Table 6: The coefficients of proposed equation for all specimens in this paper and the experimental elasticity modulus values.

\begin{tabular}{|c|c|c|c|c|c|}
\hline \multirow{2}{*}{ Notation } & \multicolumn{3}{|c|}{$\sigma=A \times \varepsilon-B \times \varepsilon^{2}$} & \multicolumn{2}{|c|}{ Elasticity modulus (MPa) } \\
\hline & $\mathrm{A}(\mathrm{MPa})$ & $\mathrm{B}(\mathrm{MPa})$ & Coefficient of Determination $\left(R^{2}\right)$ & E Chord & $\mathrm{E}_{\text {Tangent }}$ \\
\hline NAC & 33859 & $-8 . E+06$ & 0.9987 & 28830 & 29651 \\
\hline RA1C & 27079 & $-6 . E+06$ & 0.9991 & 23437 & 20559 \\
\hline RA2C & 29361 & $-5 . E+06$ & 0.9988 & 25167 & 23261 \\
\hline RA12C & 26723 & $-6 . E+06$ & 0.9987 & 22896 & 20483 \\
\hline RA123C & 12290 & $-4 . E+06$ & 0.8070 & 13805 & 9863 \\
\hline RA1CSF5 & 28238 & $-5 . E+06$ & 0.9982 & 25541 & 22805 \\
\hline RA2CSF5 & 29401 & $-5 . E+06$ & 0.9998 & 25571 & 23968 \\
\hline RA12CSF5 & 25609 & $-5 . E+06$ & 0.9991 & 22026 & 19576 \\
\hline RA123CSF5 & 18197 & $-2 . E+06$ & 0.9988 & 17668 & 15424 \\
\hline NACSF10 & 32392 & $-5 . E+06$ & 0.9989 & 27721 & 25692 \\
\hline RA1CSF10 & 30028 & $-6 . E+06$ & 0.9973 & 24968 & 22828 \\
\hline RA2CSF10 & 30978 & $-6 . E+06$ & 0.9979 & 21162 & 23738 \\
\hline RA12CSF10 & 26096 & $-5 . E+06$ & 0.9977 & 22098 & 20596 \\
\hline
\end{tabular}

\subsubsection{Theoretical elasticity modulus calculation}

In this study, in the first step, the experimental results of concretes (NAC and RAC with and without SF) are compared with the results of the codes [5],[6],[9],[17]. The standards propose elasticity modulus formulas for NAC. Hence, the modulus of elasticity prediction ability of the codes for RAC is analyzed and is compared with the experimental results. In the second step, due to the difference between the theoretical and experimental the results of codes, it is considered that elasticity modulus formulas proposed for RAC may give approximate results. In the literature researchers offered some formulas for elasticity modulus of RAC (i.e., [40],[49],[36]). However, the offered formulas for RAC differ to each other due to the parameters and ingredients utilized in mixes (i.e., NA type, RA ratios, and water to binder ratio $(\mathrm{w} / \mathrm{b}))$. Ravindrarajah and Tam [39] produced 9 mixes at various $\mathrm{w} / \mathrm{b}$ ratios and proposed an elasticity modulus equation for RAC. 15 mixes at various $\mathrm{w} / \mathrm{b}$ ratios from 0.40 to 0.60 are produced by Corinaldesi [16] and Corinaldesi proposed an equation to estimate RAC elasticity modulus. Then the results of the equation proposed by Corinaldesi were compared with the results of elasticity modulus equations given in literature. The same approach was followed by Dhir et al. [33]. In their work, 13 mixes were produced and an equation was offered by [33]. In [40], the procedure is different. A review is conducted and over 1200 test results are examined and using the data a formula of elasticity modulus composed [40]. Beside, 15 concrete mixes including RA $(0-100 \%)$ at constant $\mathrm{c} / \mathrm{b}$ of 0.5 are produced in this experimental study. An equation is to estimate moduli of elasticity. The considered equations given in the literature and standards are shown in Table 7. Also, the results of the equations are given in the Table 8.

\section{Results and discussions}

According to the results (Table 8), the elasticity modulus decreases when RA incorporation ratio increases in concrete. The elasticity modulus is dependent on the phases of stiffness (these are interfacial transition zones, cement paste and aggregates) [25]. RA with low properties (i.e. higher porosity, low elasticity modulus) decreases compressive strength of concrete [26]. This leads peak stress decrease with an increase of RA ratio in concrete and it is revealed that the values of elastic energy capacities decrease [50]. Also SF utilization in RAC improved the strength of RAC [3], and SF increase the peak value of compressive strength as a result of the pozzolanic and filler effect of SF improve the compressive strength [3],[37]. Due to the porous structure of RA, the cement part and SF can pass through the aggregate, the adhesion capacity increases (here, the adhesion occurs between hydrated cementitious matrix and the aggregates)

Moreover, the healing effect repair the cracked structure of RA and so reduce the cracks in RA when SF blended cement paste 
is cured long. On the other hand, the bond in concrete (between RAC and the new cement paste) improves [36], thus the elasticity modulus increases. For instance, when the elasticity modulus of mixes RA123C, RA123CSF5 and RA123CSF10 are considered, the results are $13805 \mathrm{MPa}, 17668 \mathrm{MPa}$ and 21581 $\mathrm{MPa}$, respectively.

Table 8 also presents the test results of the elasticity modulus normalized with NAC. It is found that EN-1992-1-1 [9] and TS 500 [5] predict the moduli of elasticity in comparison to relative chord moduli of elasticity results with higher relative average elasticity modulus values (1.143 and 1.101, respectively) and these codes (TS and EN) overestimate the elasticity moduli of concretes in comparison to relative tangent elasticity modulus results with higher relative average elasticity modulus values

Table 7: Elasticity modulus equations.

\begin{tabular}{|c|c|}
\hline References & Equations \\
\hline TS 500 [5] & $\begin{array}{c}E=14000+3250 \sqrt{f_{c y l}} \\
(\mathrm{MPa})\end{array}$ \\
\hline ACI 318M-05 [6] & $\begin{array}{c}E=4700 \sqrt{f_{c y l}} \\
(\mathrm{MPa})\end{array}$ \\
\hline EN-1992-1-1 [9] & $\begin{array}{c}E=22\left(f_{c y l} / 10\right) 0,3 \\
(\mathrm{GPa})\end{array}$ \\
\hline CSA A23.3-04 [7] & $\begin{aligned} E= & 4500 \sqrt{f_{c y l}} \\
& (\mathrm{MPa})\end{aligned}$ \\
\hline Ravindrarajah and Tam [31] & $\begin{array}{c}E=7770 f_{c u} 0.33 \\
(\mathrm{MPa})\end{array}$ \\
\hline Dhir et al. [32] & $\begin{array}{c}E=370 f_{c u}+13100 \\
(\mathrm{MPa})\end{array}$ \\
\hline Corinaldesi [34] & $\begin{array}{c}E=18800^{3} \sqrt{\left(0.83 f_{c u} / 10\right)} \\
(\mathrm{MPa})\end{array}$ \\
\hline Xiao et al. [35] & $\begin{array}{c}E=10^{5} /\left(2.8+\left(40.1 / f_{c u}\right)\right) \\
(\mathrm{MPa})\end{array}$ \\
\hline Proposed & $\begin{array}{c}E=160000 f_{c y l} /\left(225+0.4 f_{c y l}\right) \\
(\mathrm{MPa})\end{array}$ \\
\hline
\end{tabular}

Table 8(a): The theoretical and the statistical values of the elasticity modulus.

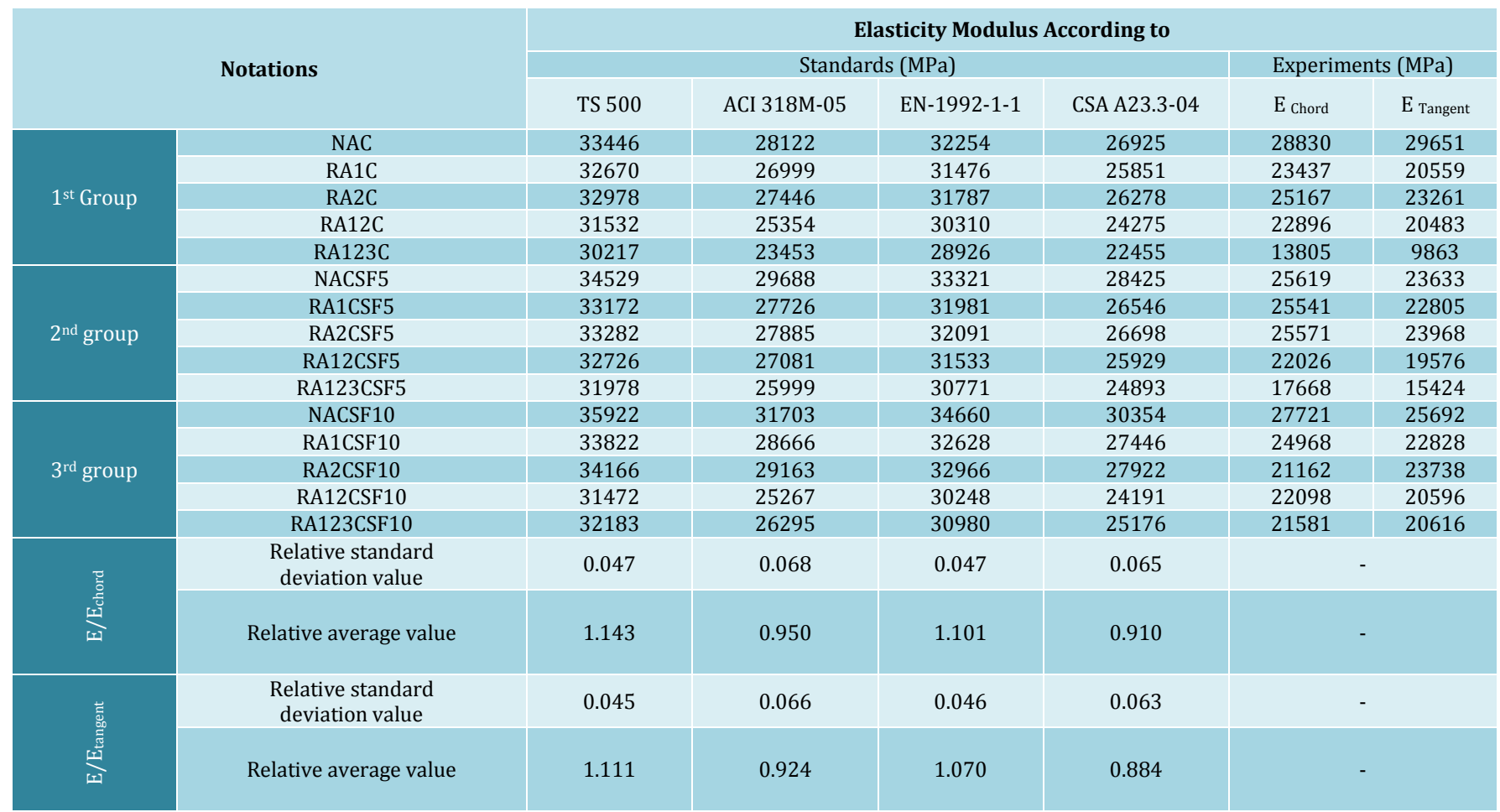

Table 8(b): The theoretical and the statistical values of the elasticity modulus. 


\begin{tabular}{|c|c|c|c|c|c|c|}
\hline & \multirow{3}{*}{ Notations } & \multicolumn{5}{|c|}{ Elasticity modulus according to } \\
\hline & & \multicolumn{5}{|c|}{ The studies in literature (MPa) } \\
\hline & & $\begin{array}{c}\text { Ravindrarajah } \\
\text { and Tam [43] }\end{array}$ & Dhir et al.[44] & Corinaldesi [47] & Xiao et al. [48] & Proposed \\
\hline \multirow{5}{*}{$1^{\text {st }}$ group } & NAC & - & - & - & - & - \\
\hline & RA1C & 26089 & 28973 & 35475 & 23551 & 23791 \\
\hline & RA2C & 26373 & 29502 & 36062 & 23813 & 24479 \\
\hline & RA12C & 25029 & 27097 & 33313 & 22523 & 21301 \\
\hline & RA123C & 23774 & 25077 & 30815 & 21202 & 18533 \\
\hline \multirow{5}{*}{$2^{\text {nd }}$ group } & NACSF5 & - & - & - & - & - \\
\hline & RA1CSF5 & 26550 & 29839 & 36430 & 23974 & 24915 \\
\hline & RA2CSF5 & 26651 & 30031 & 36639 & 24064 & 25162 \\
\hline & RA12CSF5 & 26141 & 29069 & 35583 & 23600 & 23916 \\
\hline & RA123CSF5 & 25447 & 27819 & 34161 & 22939 & 22268 \\
\hline \multirow{3}{*}{$3^{\text {rd }}$ group } & NACSF10 & - & - & - & - & - \\
\hline & RA1CSF10 & 27141 & 30993 & 37665 & 24493 & 26389 \\
\hline & RA123CSF10 & 25638 & 28155 & 34549 & 23124 & 22715 \\
\hline \multirow{2}{*}{$\begin{array}{l}\frac{11}{11} \\
\frac{11}{2} \\
\frac{2}{0} \\
0\end{array}$} & $\begin{array}{l}\text { Relative standard } \\
\text { deviation value }\end{array}$ & 0.194 & 0.193 & 0.238 & 0.171 & 0.124 \\
\hline & Relative average value & 1.199 & 1.326 & 1.622 & 1.080 & 1.002 \\
\hline \multirow{2}{*}{ 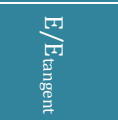 } & $\begin{array}{l}\text { Relative standard } \\
\text { deviation value }\end{array}$ & 0.350 & 0.350 & 0.433 & 0.309 & 0.209 \\
\hline & Relative average value & 1.341 & 1.480 & 1.811 & 1.208 & 1.113 \\
\hline
\end{tabular}

It is thought that the studies' elasticity moduli prediction ability $[16],[39],[33],[40]$ is noticeably weaker than codes. It should be noted that, although the codes considered in this paper are designed for NAC, they are suitable to predict elasticity modulus of RAC, as well. On the other hand, the formulas offered by [16],[39],[33],[40] predict weaker results than the codes in comparison to chord and tangent elasticity modulus values (Table 8 and Figure 5).

The highest values owned by Corinaldesi (1.622 and 1.811) [16]. However, the smallest relative standard deviations $(0.171$ and 0.309 ) and relative average values (1.080 and 1.208) obtained for Xiao et al. [40] except for the proposed formula. The results of Xiao et al. [40] are closer with experimental results in comparison to relative average elasticity modulus values than others [16],[33],[39]. This might be due to the number of examined test results. Xiao et al. [40] considered over 1200 test results in their research while others examined limited numbers of their test results. Large number of test data gives opportunity to compose a formula which predicts more precise results.

According to the codes and the studies considered in this experimental and analytical study, ACI $318 \mathrm{M}-05$ [6] in comparison to codes [5],[7],[9] and Xiao et al. [49] in comparison to the studies [16],[33],[39],[40] give approximate results. However, when the elasticity modulus obtained by using equations proposed by Xiao et al. [40] and given in ACI $318 \mathrm{M}-05$ [6] are compared with the experimental elasticity modulus, the equations proposed by Xiao et al. [40] and given by ACI $318 \mathrm{M}-05$ [6] are commenced to give results unsuitably with an increase of RA ratio from $0 \%$ to $100 \%$ in mixes. For instance, when the results of RA1C and RA123C are considered, the chord elasticity modulus are $23437 \mathrm{MPa}$ and $13805 \mathrm{MPa}$, respectively, and the tangent elasticity modulus are $20559 \mathrm{MPa}$ and $9863 \mathrm{MPa}$, respectively.

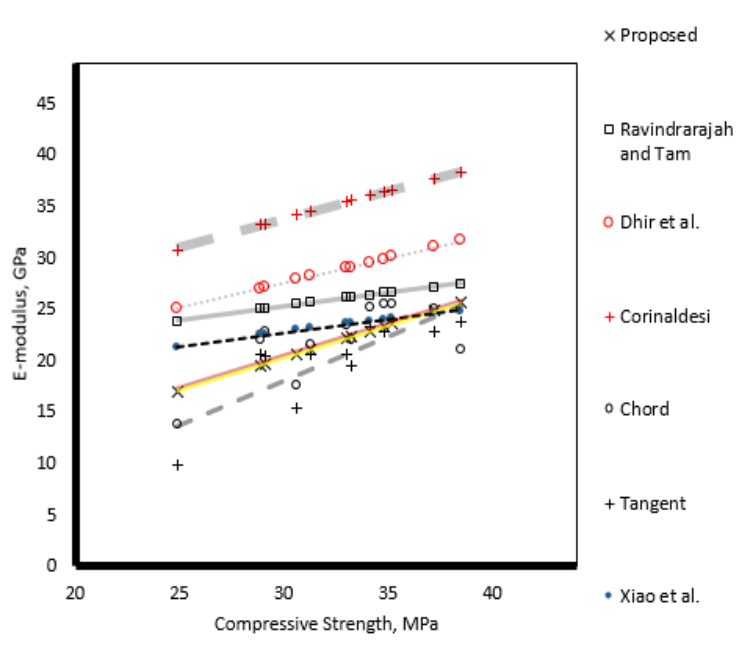

Figure 5: The elasticity moduli results of the specimens according to the equations.

On the other hand, the results of Ref. [40] for RA1C and RA123C are $23551 \mathrm{MPa}$ and $21202 \mathrm{MPa}$, respectively, and the results of ACI 318M-05 [6] for RA1C and RA123C are $26999 \mathrm{MPa}$ and $23453 \mathrm{MPa}$, respectively. It is can be seen that the difference between the results is clear, especially for RAC included $100 \%$ RA.

In this concept, generalization of formula for RAC may not be suitable due to various effective parameters (i.e., RA impurities, $\mathrm{SP}, \mathrm{w} / \mathrm{b}$ ) on RAC. The formula offered by Xiao et al. [40] do not give approximate results with the experimental results and the relative standard deviations are obtained for this research. Hence, it can be concluded that distinctive elasticity modulus formulas may be composed for each different mixes/studies due to the variety in parameters.

As demonstrated in Table 8, the proposed formula predicts modulus of elasticity most approximately with experimental 
results (i.e., tangent and chord modulus of elasticity). The smaller relative standard deviation (0.124) is determined for the proposed formula in comparison to those of studies [39],[33],[16] and the minimum average elasticity modulus (1.002) of the proposed formula is obtained. Also, in comparison to the relative tangent elasticity modulus, the minimum relative standard deviation (0.209) and the minimum relative elasticity modulus (1.113) values are calculated for the proposed equation. As can be seen in Figure 5, trend line of the results of the formulas given in [16],[33],[39],[40] and the proposed equation are approximately similar. The highest estimation of Corinaldesi [16] is visible in Figure 5, and it can be seen that the slope of the trend line of the equation given in [40] is the lowest.

\section{Conclusion}

In this research, the experimental moduli of elasticity of fifteen concrete mixes with and without SF are analyzed in comparison to the theoretical formulas of codes and the proposed elasticity modulus equations of RAC by researchers are presented.

According to the results, the followings can be drawn:

- While increasing RA ratio in concrete, the elasticity modulus decreases. SF utilization in RAC increases the moduli of elasticity and compressive strength,

- In the evaluation of the modulus of elasticity, TS 500 [5] overestimates the elasticity modulus whereas ACI 318M-05 [6] estimates the relative average elasticity modulus values close in comparison to those of considered codes although it has the highest relative standard deviations in comparison to the regarded codes,

- $\quad$ The prediction ability of the codes considered in this paper is stronger than the studies considered in this paper. The proposed equations by researchers estimate the elasticity modulus greater than those of standards although the researchers propose the formulas specifically for RAC. Moreover, the considered equations display high deviations with the increase of RA fraction in RAC, especially for RAC incorporated $100 \% \mathrm{RA}$,

- A generalized elasticity modulus equation for RAC may not be suitable due to the various effective parameters (i.e., impurities in RA, SP, and w/b) on RAC. A distinctive elasticity modulus formula derivation might be more suitable for each different mixes/studies. Hence, an equation is proposed for the elasticity modulus in this paper.

\section{Acknowledgements}

This work forms a part of the MSc thesis which was submitted by the first author to Institute of Science and Technology of Yildiz Technical University, Istanbul.

\section{References}

[1] Xiao J, Li W, Fan Y, Huang X. "An overview of study on recycled aggregate concrete in China (1996-2011)". Construction and Building Materials, 31, 364-83, 2012.

[2] Wagih AM, El-Karmoty HZ, Ebid M, Okba SH. "Recycled construction and demolition concrete waste as aggregate for structural concrete". HBRC Journal, 9(3), 193-200, 2013.
[3] Dilbas H, Şimşek M, Çakır Ö. "An investigation on mechanical and physical properties of recycled aggregate concrete (RAC) with and without Silica Fume". Construction and Building Materials, 61, 50-59, 2014.

[4] Çakır Ö. "Experimental analysis of properties of recycled coarse aggregate (RCA) Concrete with Mineral Additives". Construction and Building Materials, 68, 17-25, 2014.

[5] Turkish Standards Institute. "Requirements for Design and Construction of Reinforced Concrete Structures". Ankara, Turkey, TS 500, 2000.

[6] American Concrete Institute. "Building Code Requirements for Structural Concrete and Commentary". Farmington Hills, MI, USA, ACI-318M-05, 2004.

[7] Canadian Standards Association. "Design of Concrete Structures". Mississauga, Ontario, Canada, CSA A23.3-04, 2010.

[8] Concrete and Reinforced Concrete Research and Technology Institute. "Concrete and Reinforced Concrete Structures without Prestressing". Moscow, Russia, SP 52-101-2003, 2006.

[9] European Committee for Standardization. "Design of Concrete Structures-Part 1-1: General Rules for Buildings". Brussels, Belgium, EN 1992-1-1, 2004.

[10] Standards Australia. "Australian Standard Concrete Structures". GPO Box 5420, Sydney, Australia, AS-3600-2001, 2001.

[11] Nematzadeh M, Naghipour M. "Compressive strength and modulus of elasticity of freshly compressed concrete". Construction and Building Materials, 34, 476-485, 2012.

[12] Vilanova A, Fernandez-Gomez J, Landsberger GA. "Evaluation of the mechanical properties of selfcompacting concrete using current estimating models". Construction and Building Materials, 25, 3417-3426, 2011.

[13] Zhou C, Li K, Ma F. "Numerical and statistical analysis of elastic modulus of concrete as a three-phase heterogeneous composite". Computers and Structures, 139, 33-42, 2014.

[14] Pronzin A. Comparison of Russian, Finnish and European Norms for Reinforced Concrete Structures. BSc Thesis, Saimaa University, Lappeenranta, Finland, 2012.

[15] Demir F, Korkmaz A. "Prediction of lower and upper bounds of elastic modulus of high strength concrete". Construction and Building Materials, 22, 1385-1393, 2008.

[16] Corinaldesi V. "Mechanical and elastic behaviour of concretes made of recycled-concrete coarse aggregates". Construction and Building Materials, 24, 1616-1620, 2010.

[17] China National Institute of Standardization. "Code for design of concrete structures". China, GB 50010, 2010.

[18] Yıldırım H, Sengul O. "Modulus of elasticity of substandard and normal concretes". Construction and Building Materials, 25, 1645-1652, 2011.

[19] Belén GF, Fernando MA, Diego CL, Sindy SP. "Stress-Strain relationship in axial compression for concrete using recycled saturated coarse aggregate". Construction and Building Materials, 25, 2335-2342, 2011.

[20] Sheen YN, Wang HY, Juang YP, Le DH. "Assessment on the engineering properties of ready-mixed concrete using recycled aggregates". Construction and Building Materials, 45, 298-305, 2013.

[21] Martínez-Lage I, Martínez-Abella F, Vázquez-Herrero C, Pérez-Ordóñez. JL. "Properties of plain concrete made with mixed recycled coarse aggregate". Construction and Building Materials, 37, 171-176, 2012. 
[22] Soares D, Brito J De, Ferreira J, Pacheco J. "Use of coarse recycled aggregates from precast concrete rejects: mechanical and durability performance". Construction and Building Materials, 71, 263-272, 2014.

[23] de Brito J, Barra M, Ferreira L. "Influence of the presaturation of recycled coarse concrete aggregates on concrete properties". Magazine of Concrete Research, 63, 617-627, 2011.

[24] Soares D, de Brito J, Ferreira J, Pacheco J. "In situ materials characterization of full-scale recycled aggregates concrete structures". Construction and Building Materials, 71, 237-245, 2014.

[25] Fonseca N, de Brito J, Evangelista L. "The influence of curing conditions on the mechanical performance of concrete made with recycled concrete waste". Cement and Concrete Composites, 33, 637-643, 2011.

[26] Pedro D, de Brito J, Evangelista L. "Influence of the Use of recycled concrete aggregates from different sources on structural concrete". Construction and Building Materials, 71, 141-151, 2014.

[27] Silva RV, de Brito J, Dhir RK. "Properties and composition of recycled aggregates from construction and demolition waste suitable for concrete production". Construction and Building Materials, 65, 201-217, 2014.

[28] Poon CS, Chan D. "Effects of contaminants on the properties of concrete paving blocks prepared with recycled concrete aggregates". Construction and Building Materials, 21, 164-175, 2007.

[29] Etxeberria M, Vázquez E, Marí A, Barra M. "Influence of amount of recycled coarse aggregates and production process on properties of recycled aggregate concrete". Cement and Concrete Research, 37, 735-742, 2007.

[30] Kou SC, Poon CS. "Long-Term mechanical and durability properties of recycled aggregate concrete prepared with the incorporation of fly Ash". Cement and Concrete Composite, 37, 12-19, 2013.

[31] Berndt MLL. "Properties of sustainable concrete containing fly ash, slag and recycled concrete aggregate". Construction and Building Materials, 23, 2606-2613, 2009.

[32] Corinaldesi V, Moriconi G. "Influence of mineral additions on the performance of $100 \%$ recycled aggregate concrete". Construction and Building Materials, 23, 2869-2876, 2009.

[33] Dhir RK, Limbachiya MC, Leelawat T. "Suitability of recycled concrete aggregate for use in BS5328 designated mixes". Proceedings of the Institution of Civil EngineersStructures and Buildings, 1 January 1998.

[34] Dillmann R. "Concrete with recycled concrete aggregate". Proceedings of International Symposium on Sustainable Construction: Use of Recycled Concrete Aggregate, Dundee, Scotland, 11-12 November 1998.

[35] Kakizaki M, Harada M, Soshiroda T, Kubota S, Ikeda TKY. "Strength and elastic modulus of recycled aggregate concrete". $2^{\text {nd }}$ International RILEM Symposium on Demolition and Reuse of Concrete and Masonry, Tokyo, Japan, 7-11 November, 1988.
[36] Abd Elhakam A, Mohamed AE, Awad E. "Influence of selfhealing, mixing method and adding silica fume on mechanical properties of recycled aggregates concrete". Construction and Building Materials, 35, 421-427, 2012.

[37] González-Fonteboa B, Martínez-Abella F. "Concretes with aggregates from demolition waste and silica fume". materials and mechanical properties". Building and Environment, 43, 429-437, 2008.

[38] Dilbas H, Çakır Ö, Şimşek Ö. "Recycled aggregate concretes (racs) for structural use: an evaluation on elasticity modulus and energy capacities". International Journal of Civil Engineering, 15, 247-261, 2017.

[39] Sri Ravindrarajah R, Tam CT. "Properties of concrete made with crushed concrete as coarse aggregate". Magazine of Concrete Research, 37, 29-38, 1985.

[40] Xiao JZ, Li J-B, Zhang C. "On relationships between the mechanical properties of recycled aggregate concrete: an overview". Materials and Structures, 39, 655-664, 2007.

[41] Turkish Standards Institute. "Design of Concrete Mixes". Ankara, Turkey, TS 802, 2016.

[42] Turkish Standards Institute. "Testing Hardened Concrete Part 2: Making and Curing Specimens for Strength Tests". Ankara, Turkey, TS 12390-2, 2010.

[43] Turkish Standards Institute. "Tests for Mechanical and Physical Properties of Aggregates-Part 6: Determination of Particle Density and Water Absorption". Ankara, Turkey, TS EN 1097-6/AC, 2013.

[44] Turkish Standards Institute. "Tests for Mechanical and Physical Properties of Aggregates - Part 2: Methods for the Determination of Resistance to Fragmentation". Ankara, Turkey, TS EN 1097-2, 2010.

[45] Turkish Standards Institute. "Tests for Chemical Properties of Aggregates-Part 1: Chemical Analysis". Ankara, Turkey, TS EN 1744-1, 2011.

[46] Turkish Standards Institute. "Testing Hardened Concrete Part 3: Compressive Strength of Test Specimens". Ankara, Turkey, TS EN 12390-3, 2010.

[47] American Society for Testing and Materials. "Standard Test Method for Static Modulus of Elasticity and Poisson's Ratio of Concrete in Compression". West Conshohocken, PA, USA, ASTM C469/C469M-14, 2014.

[48] Haktanır T. "Experimental Determination of Modulus of Elasticity of Concrete". 1 $1^{\text {st }}$ International Conference on Concrete Technology, Tabriz, Iran, 6-7 November, 2009.

[49] Duan ZH, Poon CS. "Properties of recycled aggregate concrete made with recycled aggregates with different amounts of old adhered mortars". Materials and Design, 58, 19-29, 2014.

[50] Xiao J, Li J, Zhang C. "Mechanical properties of recycled aggregate concrete under uniaxial loading". Cement and Concrete Research, 35, 1187-1194, 2005. 